\title{
Presidential rhetoric in times of crisis: A textual analysis of speeches by franklin roosevelt and ronald reagan
}

\author{
Samantha D. Cart \\ West Virginia University
}

Follow this and additional works at: https://researchrepository.wvu.edu/etd

\section{Recommended Citation}

Cart, Samantha D., "Presidential rhetoric in times of crisis: A textual analysis of speeches by franklin roosevelt and ronald reagan" (2014). Graduate Theses, Dissertations, and Problem Reports. 148.

https://researchrepository.wvu.edu/etd/148

This Thesis is protected by copyright and/or related rights. It has been brought to you by the The Research Repository @ WVU with permission from the rights-holder(s). You are free to use this Thesis in any way that is permitted by the copyright and related rights legislation that applies to your use. For other uses you must obtain permission from the rights-holder(s) directly, unless additional rights are indicated by a Creative Commons license in the record and/ or on the work itself. This Thesis has been accepted for inclusion in WVU Graduate Theses, Dissertations, and Problem Reports collection by an authorized administrator of The Research Repository @ WVU. For more information, please contact researchrepository@mail.wvu.edu. 
Presidential Rhetoric in Times of Crisis:

A Textual Analysis of Speeches by Franklin Roosevelt and Ronald Reagan

Samantha D. Cart

\author{
Thesis submitted to the \\ Perley Isaac Reed School of Journalism \\ at West Virginia University \\ in partial fulfillment of the requirements \\ for the degree of
}

Master of Science

in

Journalism

Steve Urbanski, Ph.D., Chair

Diana Martinelli, Ph.D.

April Johnston, M.F.A.

Elizabeth Fones-Wolf, Ph.D

Department of Journalism

Morgantown, West Virginia

2014

Keywords: Franklin Roosevelt, Ronald Reagan, presidential speech, crisis rhetoric Copyright 2014: Samantha Cart 

ABSTRACT
Presidential Rhetoric in Times of Crisis:
A Textual Analysis of Speeches by Franklin Roosevelt and Ronald Reagan
Samantha D. Cart

While many scholars have examined the rhetoric of presidents Franklin Roosevelt and Ronald Reagan individually, there is a gap in literature concerning crisis rhetoric specifically and little has been done in the way of comparing these two men. This study is a textual analysis of six speeches given by Roosevelt and Reagan during times of crises. Because both presidents were important in defining an era and considered great communicators, this study compares the similarities and differences of their use of presidential crisis rhetoric. Previous research shows clear patterns in presidential rhetoric, including the common use of civil religious words and symbols, collective focus and imagery. This study analyzes Roosevelt's and Reagan's speeches for the use of predefined and common rhetorical devices in times of crisis.

In the six speeches studied, the analysis indicated that each president regularly used the uplifting of democracy and civil religion when addressing the nation in times of crisis. Also, the research suggests that the presidents' differing political affiliations influenced the way they spoke about the use of the Constitution and their executive power in order to address crises. Thus, Roosevelt and Reagan's use of the pre-defined rhetorical terms listed in this study and the use of political party-specific rhetoric concerning the power of the executive branch may have influenced the effectiveness of their overall crisis rhetoric in regard to United States' citizens and may offer a broader understanding and interpretation of the contemporary political world. 


\section{ACKNOWLEDGEMENTS}

Thank you to my parents, Michael and Tina, and my husband, Caleb, who have always supported me in every possible way.

And thank you to Dr. Steve Urbanski, without whom this paper would never have been finished. 


\section{TABLE OF CONTENTS}

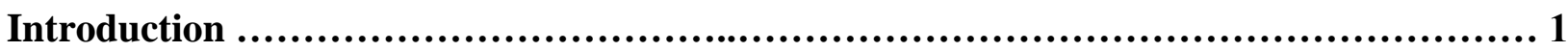

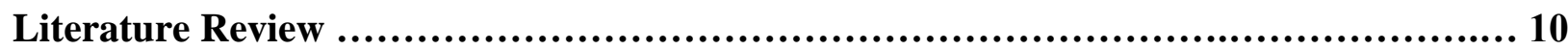

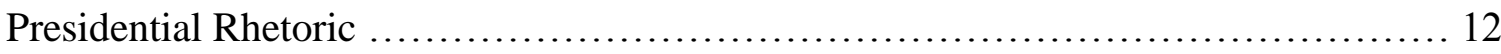

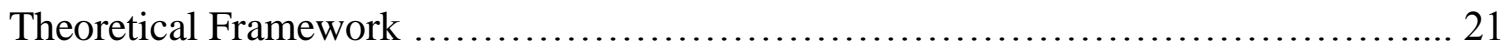

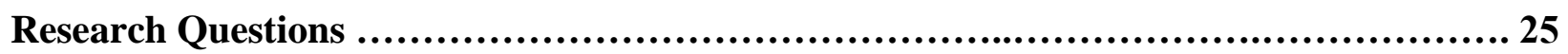

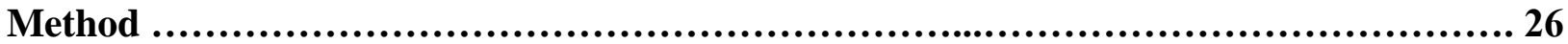

Table 1: Operationalization of Rhetorical Devices ............................... 28

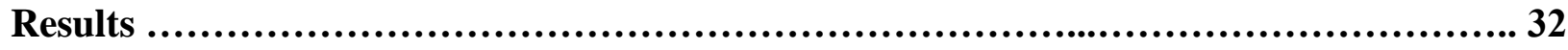

Table 2: Examples of Rhetorical Devices ........................................... 39

Discussion \& Implications .................................................................. 41

Limitations and Future Research ................................................ 42

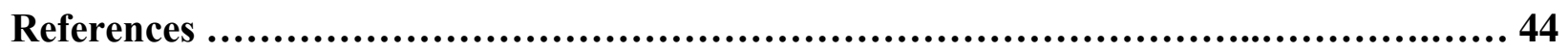




\section{INTRODUCTION}

To be a politician in America, or more specifically to be the President of the United States, no doubt requires vast knowledge of many topics and a variety of skills. In a world where the American public view is constantly shifting, where media presence is more important than past voting records and where the president is often equal parts public figure and celebrity, the ability to perform is a determining factor in whether a man or woman is considered an able leader (Renka, 2010). It is the media, i.e. the radio, not the minutes from the Capitol; the newspaper, not the bill that was just signed into law; and the television appearance, not the letter written to a constituent, that offers vast exposure and most likely helps determine whether a candidate will hold the prestigious office of president.

In this mediated climate, one quality citizens likely value in a leader is the ability to anticipate and handle change. This quality is facilitated through the ability to reassure citizensto comfort and inspire through the spoken word. A modern president must be able to use speech and rhetoric to his or her strongest advantage to anticipate, address or mediate crisis (Davis \& Gardner, 2012). Times of crisis in America can be defining moments in a political career and many have had the opportunity to change the national climate with their words and mastery of rhetorical strategies.

Franklin Delano Roosevelt, the $32^{\text {nd }}$ president, and Ronald Wilson Reagan, the $40^{\text {th }}$ president, are two examples of such leaders. Considered to be great communicators of their generations, the two former presidents embodied the skills and rhetoric that seem so vital for success in the eyes of the electorate. There were distinct differences in the media tools available to these two politicians. For example, Roosevelt's primary media tools were his famous Fireside Chats via radio while Reagan reached the electorate primarily through television appearances (with which he was well acquainted due to his career as an actor). Roosevelt and Reagan were 
both heavily involved in writing his their own speeches, but also had several professional speech writers. Reagan's speech writers included well-known names such as Peggy Noonan ${ }^{1}$ and Peter Robinson $^{2}$. This study will utilize textual analysis to compare speeches given by Roosevelt and Reagan. To this end, the study will focus on the similarities and differences in their crisis rhetoric and their frequently used rhetorical devices. While research has been done on the various facets of presidential rhetoric in general, especially that of Roosevelt and Reagan individually, there is a gap concerning crisis rhetoric specifically and there has been little done in the way of comparing these two men who possessed such powerful communication skills. This analysis will also include insight into the role their differences played in their rhetorical presidencies. The rhetorical presidency has been defined as the description of the communication and governing style of U.S. presidents in the $20^{\text {th }}$ century. It is both a theory and a genre of presidential rhetoric and is strongly influenced by the media age (Tulis, 1987).

\section{Background}

Franklin Roosevelt. In 1933, Franklin D. Roosevelt was inaugurated as President of the United States for his first term. He had just been elected over incumbent Herbert Hoover in a race grounded primarily in the economy. Roosevelt's exemplary rhetoric was obvious long before his election to the presidency - it could be seen in his role as governor of New York and in his presidential campaign, which was an attack on Hoover's failure to keep the country out of the spiraling Depression and sold Americans his vague platform called the New Deal (Ritchie, 2007). When Roosevelt took office, American citizens were unsatisfied with the government

\footnotetext{
${ }^{1}$ Margaret Ellen "Peggy" Noonan is an American author, journalist and former special assistant and presidential speech writer for Ronald Reagan (1984 - 1986). She is well known for writing Reagan's address to the nation after the Challenger explosion (Noonan).

${ }^{2}$ Peter Robinson is an author, television host and former White House speechwriter who joined President Reagan's staff in 1983. He served as a special assistant and speech writer to Reagan for five years and wrote over 300 of his speeches, including the 1987 Berlin Wall address (Dartmouth).
} 
and the state in which the Great Depression had left many-with growing unemployment and steadily declining wages. A frighteningly similar economic profile was evident in Germany at this time. Hitler's Nazi regime had finally taken hold (after several failed attempts during good economic times), suggesting that rhetoric seems to be most powerful in times of desperation. Roosevelt wasted no time when entering office, and began his administration with what came to be known as the "first hundred days." Walter Lippmann, a noted journalist at the time, said, "At the end of February we were a congeries of disorderly panic-stricken mobs and factions. In the hundred days from March to June we became again an organized nation confident of our power to provide for our own security and to control our own destiny" ("Section II: Franklin D. Roosevelt and The New Deal," n.d.).

Some of the New Deal's most famous legislation came out of the first hundred days, which established the Civilian Conservation Corps, the Public Works Administration Act and the Federal Deposit Insurance Corporation. All of these answered the call made by American citizens for solutions to the economic crunch, and all of them seem to have been sold to America and its Congress by the crisis situation and by Roosevelt's ability to evoke emotion through speech (Ryan, 1988). In other words, Roosevelt listened to the electorate, something that is not necessarily present in today's vicious political climate (Ryan, 1988). In March 1933, Roosevelt held his first Fireside Chat (as they came to be called after the first one on banking), which would become an important symbol of his presidency and of which rhetoric was a crucial aspect.

Roosevelt's Fireside Chats came at a profound moment in history. The timing of the political climate, the availability of technology and Roosevelt's own personal life could not have been more ideal. Roosevelt had already had some success with radio during his governorship, during which he addressed the residents of New York State about once every 10 days. He 
initially chose this form of communication because of his affliction with poliomyelitis, which occurred in 1921 and made travel difficult. However, his recognizable and strong radio voice coupled with the increase in the number of home radio sets and the extension of radio networks made radio the obvious choice for how the new president would address the American people (Braden \& Bradenburg, 1955). This allowed his audience to become conditioned to his voice instead of his image. Roosevelt's use of this medium to broadcast his Fireside Chats increased his own popularity and the popularity of the radio. The radio provided many advantageous opportunities for Roosevelt, including the ability to minimize his disability, gain support from then current and future voters (which would lead to his being elected to four terms in office and subsequently inspire the two-term limit), gain support for his social programs and create a seemingly personal relationship with the American people.

The primary importance of the Fireside Chats was to gain popular support for Roosevelt's proposed measures. This style was highly efficient, especially during the period of the global economic downturn, and helped him "mobilize and organize a mass public behind his New Deal policies” (Ryfe, 1999, p. 81). According to Winfield (1990), the radio allowed Roosevelt to "escape the mediation of other political actors, most notably the Congress and reporters, to speak directly to the public" (p. 104). Grace Tully, who worked on Roosevelt's campaign and served as his private secretary from 1941-1945, wrote that Roosevelt had a lot of respect for the power of public opinion.

Throughout his 12-year presidency, Roosevelt gave roughly 28 fireside chats as well as various other radio addresses. His talents as an orator made elucidating on a major crisis seem easy by creating a simple conversation with the American people. Having his voice in the living room of American families helped Roosevelt form a sense of identity and an "imagined 
community" (Dayan \& Katz, 1992) between them. Roosevelt thought of his audience "in family groups. He thought of them sitting on a suburban porch after supper on a summer evening. He thought of them gathered around a dinner table at a family meal” (Perkins, 1946, p. 71). He focused on the psychology of his audiences to construct his radio appeals, including going in such depth as to practice reading each address out loud to note the rhythm of the words and comment on word length (Ryfe, 1999).

Roosevelt knew exactly how to address the American people. For example, during a particularly tense time in his career when legislation was increasing furiously, but things did not seem to be getting any easier and German pressure for territory in Europe was intensifying, Roosevelt started his Fireside Chat 13 on June 24, 1938 by emphasizing the important role of the public in American politics:

Our government, happily, is a democracy. As part of the democratic process, your President is again taking an opportunity to report on the progress of national affairs to the real rulers of this country - the voting public (Roosevelt, 1938).

Roosevelt's political history as governor of New York already showed that he "frequently took his case to the people, hoping to create sufficient pressure to assure the success of his program[s] (Braden \& Bradenburg, 1955, p. 190).” His savvy use of radio, his use of psychology in constructing his radio appeals and his knowledge of the American people are all what made the Fireside Chats such a powerful rhetorical tool.

Roosevelt's rhetorical strategies are illustrated by his media tactics, as he incorporated various aspects of his personality that made him popular with the press. He gave authoritative answers to crucial crisis questions, which helped in setting the political agenda, convincing many Americans of the rightness of his proposals and delivering comfort to the masses in uncertain times (Ryan, 1988). He also willingly gave his own opinions on public policy and his stance on 
hot button issues; Roosevelt was committed to keeping in touch with the American people. Roosevelt's presidency was plagued with crises - the Great Depression, the banking crisis, the Supreme Court packing scandal, the bombing of Pearl Harbor, World War II- each of which gave him the opportunity and the call to invoke his presidential rhetoric to its full extent.

Ronald Reagan. Similarly, Ronald Reagan is another president that history generally reflects favorably upon (Lahlou, Schonhardt \& Yager, 2012). Best known for his economic initiatives, Reagan served as President of the United States from 1981-1989. He was well known for his career in radio, film and television before becoming the governor of California in 1967. His unique talent for speech and rhetoric were fostered by his acting career and were first noticed during his service as president of the Screen Actors Guild. He went on to serve as a spokesman for General Electric and gained acclaim for his popular speech announcing his support for Barry Goldwater's run for presidency in 1964 (Freidel, 1982). His terms were also filled with crises, which gave him the opportunity to apply his rhetorical skills and led to him being called "The Great Communicator" (Freidel, 1982). Reagan served during a noteworthy recession, survived an assassination attempt, ordered an invasion of Grenada and dealt with the 1986 bombing of Libya, the Iran-Contra affair and part of the the conclusion of the Cold War.

Reagan's rhetorical strategy was no doubt developed by his work as an actor but was first put into pseudo-political practice during his time as president of the Screen Actors Guild. Reagan was heavily involved in arguments over Communism in the film industry (Freidel, 1982). In the late 1950s, Reagan found his political views shifting from liberal to conservative and began to tour the nation as a spokesman for conservatism (Freidel, 1982). Historically, party switchers have had a hard time getting elected and are criticized for switching their votes to favor their new party. However, Reagan's party change was accepted by both the Republican Party 
and voters. Reagan is famously quoted as saying, "I didn't leave the Democratic Party. The party left me" (Time, 2009). After serving as governor of California, Reagan won the Republican presidential nomination in 1980.

While both Roosevelt and Reagan came into office with a strong message and many campaign promises, unlike Roosevelt, Reagan's was clear-cut and defined. Reagan is still known for introducing the largest across-the-board tax cuts in history. His plan to "reinvigorate the American people and reduce their reliance upon Government" (Freidel, 1982, p. 84) was termed the "Reagan Revolution" and fulfilled his 1980 campaign pledge to "restore the great, confident roar of American progress and growth and optimism" (Freidel, 1982, p. 84). American citizens were burdened by inflation and the crisis in Iran, and Reagan's rhetoric, which centered on faith in country and patriotism, helped him gain 489 electoral votes over incumbent Jimmy Carter's 49 (Freidel, 1982). "Reaganomics” became a popular term to refer to Reagan's supplyside economic policies, such as increasing government spending, reducing federal income and capital gains taxes, reducing government regulation and working to reduce inflation (Freidel, 1982).

Reagan took office on January 20, 1981 and was shot 69 days later in an attempted assassination. His quick recovery, eagerness to return to his responsibilities as president and his rhetorical wit concerning the incident helped him gain popularity quickly (Freidel, 1982). ${ }^{3}$

\footnotetext{
${ }^{3}$ On March 30, 1981, after delivering a speech at the Washington Hilton Hotel in Washington, D.C., Ronald Reagan was shot and wounded by John Hinckley, Jr. in a failed assassination attempt. Reagan was shot in his chest and right arm and sustained a punctured lung and internal bleeding (Aaron, 1994). However, Reagan recovered quickly, and gave his first speech after the attack on April 28, 1981 to discuss his program for economic recovery. While in the hospital, Reagan quoted W.C. Fields saying, "All in all, I'd rather be in Philadelphia." This, as well as his April 28 speech during which he spoke to the nation of his appreciation for its messages, flowers, prayers, "expressions of friendship" (Reagan, 1981) and love are vivid examples of his ability to connect with people in a simple but effective way (Weaver, Sweeney \& Thomas, 1984).
} 
Similar to Roosevelt, Reagan was deft at getting legislation through Congress. He promptly gained legislation to put his economic growth plan into action, a plan which included curbing inflation, increasing employment and strengthening national defense. He cut taxes and government programs, refusing to stray from his plan even though it significantly increased the national debt (Freidel, 1982). “A renewal of national self-confidence by 1984 helped Reagan and Bush win a second term with an unprecedented number of electoral votes" (Freidel, 1982, p. 85). Reagan continued with his economic plan by renovating the income tax code in his second term.

At the end of Reagan's administration, America was experiencing the longest-recorded period of peacetime prosperity without recession or depression, which makes it seems as though Reagan's times of crisis were less intense compared to those that Roosevelt faced. However, Reagan is also well known for his negotiations with the Soviet Union, which ended in a treaty eliminating intermediate-range nuclear missiles and saw Soviet Communism start to fall when he was leaving office. He also declared war against international terrorism and sent bombers against Libya in retaliation of an attack on American soldiers in a West Berlin nightclub (Freidel, 1982). His presidency is also characterized by a stock-market crash in 1987 and a series of criminal investigations of former White House officials (Hertsgaard, 1988).

Reagan's arsenal included speech writers, good looks and a popular disposition, but public memory best remembers his unfailing optimism as his most influential rhetorical device (Freidel, 1982). Just as with Roosevelt and the advent of radio, timing was on his side as the public found his light-hearted confidence appealing following backdrops such as Vietnam and Watergate. Reagan's optimistic rhetoric would come to be defined by his civil religion and his 
belief in America as an enviable place full of decent people. ${ }^{4}$ His love of country is a resounding theme in many of his speeches - most notably his 1984 tribute at Normandy, which adequately sums up his ideals of freedom:

You all knew that some things are worth dying for. One's country is worth dying for, and democracy is worth dying for, because it's the most deeply honorable form of government ever devised by man (Reagan, 1984).

His presidency is strongly associated with the revival of conservatism in America as well as a shift in the presidency itself, wherein rhetoric as communication became more strategic. In 1979, the Speech Communication Association of America even established a task force on presidential communication to assess presidential rhetoric as a chief way presidents implement the power of the office (Freidel, 1982).

In the age of mass media and the growing public relations field, Reagan's relationship with the press was vastly different from Roosevelt's. Reagan's appearances, statements and image were outlined each day, creating a new model of presidential-press relations (Hertsgaard, 1988). Reagan's public relations plans were made months in advance and reviewed and rehearsed each morning in a meeting setting (Hertsgaard, 2004). The idea behind the model was that press reports about the president inform public opinion about him or her. Thus, it became the job of people such as Michael Deaver, Richard Wirthlin and David Gergen (chief strategists for Reagan) to focus their "talents on controlling to the maximum extent possible what news reporters said about the President and his policies" (Hertsgaard, 1988, p. 3). These men

\footnotetext{
${ }^{4}$ Because of his relatability and carefully calculated rhetorical style, Reagan was perceived as an incredibly decent man (Hertsgaard, 1988). His use of civil religious rhetoric and his frequent mentions of God were popular and widely accepted. However, Reagan is the only president in U.S. history to have been divorced, a fact that is often overlooked. His first marriage to Jane Wyman lasted from 1940-1949, but ended when she filed for divorce, claiming that Reagan was too busy with his dedication to the Screen Actors Guild and his political ambitions. Reagan and Wyman had two biological children, Maureen and Christine, and one adopted child, Michael. Reagan married Nancy Davis in 1952 and together they had two children, Patricia and Ronald (Freidel, 1982).
} 
skillfully approached the media-saturated world with the understanding that only repetition of their interesting stories and appealing visuals would pierce the public consciousness (Hertsgaard, 2004). The Reagan administration was notorious for leaving the press out of sensitive issues, such as the Grenada invasion, as part of its news management strategy.

Regardless, Reagan was treated very well by the press. Press about him was overwhelmingly positive, and there was even a sense of self-censorship by the media concerning him, as if they were afraid to say anything negative about the President (Hertsgaard, 1988).

Reagan even gained the nickname of the "Teflon President" because blame never seemed to stick to him-his sunny personality made reporters shy away from speaking ill of him in print (Hertsgaard, 1988). His personality seemed to go a long way, although according to Hertsgaard, Reagan was said to have had a sense of condescension toward reporters. "He thinks of the press as poor souls who can be saved by the redemption of his superior knowledge," said one of Reagan's own speechwriters, Kenneth Khachigian (Hertsgaard, 1988, p. 46).

Whatever Reagan thought of his relationship with the press, his friendly banter kept reporters from smearing his name. This efficient press model did share a core aspect with Roosevelt's media style. The Reagan administration gave reporters information-facts, for-therecord quotes and repetition of the most important piece of the stories - however pre-packaged, controlled and limited that information was (Hertsgaard, 1988).

\section{LITERATURE REVIEW}

The topic of presidential crisis rhetoric is important because its basic tenants can be applied to any presidency on a comparative level; that is, every president has the opportunity to use crisis rhetoric to his or her advantage, but not all of them use it wisely or are charming 
enough to capture the nation. Building on prior research and pre-defined rhetorical devices, as well as using relevant information concerning modern presidents, defining the most successful rhetorical devices of two of America's notable communicators will be relevant to any future politician. This study will also complement current literature, give a more complete knowledge of presidential rhetoric in times of crisis and span both time and political parties. Research on crisis rhetoric will help inform what according to Dow (1989) is a new genre of rhetoric.

Presidential rhetoric continues to be highly studied as a way to increase campaign success and overall leadership effectiveness. Hammer (2010) conducted a rhetorical and comparative analysis of five speeches given by Barack Obama during his first primary election season to create a better understanding of twenty-first century politics and to impress upon the audience the importance of narrative and rhetoric in a strong campaign. By analyzing the rhetoric of these five speeches, it becomes clear that Obama intentionally formed an agreeable narrative that would appeal to the broadest possible coalition of voters to persuade them to elect him. He utilized the American Creed, his own political myth and symbols of an American civil religion, all of which contributed to the success of his campaign (Hammer, 2010). By utilizing the American Creed, which has words and phrases familiar to most Americans and speaks to their overwhelming dedication to freedom, Hammer suggests that Obama used the creed to create his own political myth - America as a unified nation. Obama also used the most classic example of civil religion, which has been used by every president and presidential candidate - beginning and ending speeches with a reference to God (Hammer, 2010). It is noteworthy that in Hammer's comparison of Obama to Jesse Jackson, a former candidate for the Democratic presidential nomination in 1984 and 1988, Obama uses only "God" because it can mean something different to each American, while Jackson made the mistake of using "Jesus" several 
times in one of his primary speeches - making his speech less relatable to a broader audience, and thus, less effective (Hammer, 2010). This provides an example of how rhetoric can be manipulated and used effectively to capture the largest audience.

All of these rhetorical devices combined with the power of Obama's public relations team and the popularity of social media made his campaign one unmatched in history. However, his rhetoric alone followed the patterns and used devices established by presidents long before him. Rhetoric is key to a president's success in campaigning because candidates must not only present a convincing narrative, but they must also present themselves as the "only viable representative of these stories" (Hammer, 2010, p. 270). Hammer also noted a pattern of elected presidents continuing to use the rhetoric of their campaign throughout their term. Hammer's study serves as a platform for creating new knowledge on presidential rhetoric.

\section{Presidential Rhetoric}

Rhetoric in its most basic form is effective or persuasive speaking or writing designed to have a specific effect on its audience (Casaregola, 1992). The study of presidential rhetoric is a vast, yet incomplete field of "complex transaction[s] among speakers or writers, texts or performance, audiences, and critics" (Zarefsky, 1983, p. 607). While it is not the purpose of this specific study, the rhetoric of many of the nation's presidents has never been studied at all.

There have been several studies on specific tools used by presidents such as visual metaphor and euphemism (Stuckey, 2010), civil religion and commitment (Lahlou, Schonhardt \& Yager, 2012).

Presidents use rhetoric as a governing mechanism to try to stimulate public support for their policies (Rottinghaus, 2006). While in office, presidents often use the "permanent campaign" (Rottinghaus, p. 729) to keep the public focused on issues important to them and to 
"maintain a positive image in the media" (Andrews, 2011, p. 6 ). By utilizing campaign tactics such as speeches and press conferences, presidents can stay in the public eye and create awareness for their issues while continually campaigning for the next election.

Rhetoric enables communication, and its devices are endless. Humans are saturated with rhetorical symbols and images every day (Foss, 1996). In some instances rhetoric is used to persuade, though this was a point of contention among Greek philosophers. In other instances, rhetoric is "an invitation to understanding" (Foss, 1996, p. 5), and this too is key to politics. Rhetoric can help offer perspective and invite others to enter a world and see it through the eyes of the rhetor (Foss, 1996). If indeed one of the main purposes of rhetoric is to persuade, as according to Plato, then it is obvious that rhetoric plays a huge role in politics. Audiences can simply hear a political candidate speak and not be able to pinpoint the reasons why they feel supportive of that candidate afterward. While trying their own hand at rhetoric to attract voters or champion legislation, "political candidates are often calling for 'action, not rhetoric' from their opponents or the leaders of other nations" (Foss, 1996, p. 4).

Presidential rhetoric is a research category all its own - it is well studied, much is known about it and much has been defined because of the great interest in understanding and documenting it. Presidential crisis rhetoric, however, is a much less developed genre of research. Crisis rhetoric is defined by Kiewe (1994) as "the discourse initiated by decision makers in an attempt to communicate to various constituents that a certain development is critical and to suggest a certain course of action to remedy the critical situation" (Kiewe, 1994, p. 17). When a leader is forced to use crisis rhetoric, he or she follows a long-standing pattern of legitimizing the crisis, providing relevant information to followers, calling on followers to support his or her 
crisis solution and inspiring the audience to work hard to achieve or support the goals of that “community” (Davis \& Gardner, 2012).

Despite the different personality traits or characteristics of each president, crisis rhetoric does tend to follow a pattern (Cherwitz \& Zagacki, 1986). Being two of the most important presidents in defining an era, Roosevelt and Reagan had two very distinct and well-documented personalities (Barber, 1972). It is important in a study that seeks to compare and contrast to understand that no matter who the study is contrasting, when the subjects have held the exact same role, patterns will emerge (Zarefsky, 1983). For example, Zarefsky found there is a difference in the communication initially responding to an emergency versus that accompanying, justifying and rationalizing the response to a crisis. While each president has had his own personality and considerations, research suggests that crisis discourse follows a predictable and regular pattern. This pattern can be attributed to the larger idea that how the president chooses to articulate on an occurrence (despite their individual physical and characterizing qualities) will play a huge role in how United States citizens respond to crises. Thus, they each have followed a similar pattern and these patterns vary in terms of whether the crisis is threatening to American citizens or property as opposed to foreign affairs (Cherwitz \& Zagacki, 1986).

For example, in Reagan's September 5, 1983 speech responding to the downing of a Korean airliner, there is a clear pattern of consummatory discourse. In contrast to justificatory discourse, during which a president typically explains and rationalizes military retaliation as a response to a crisis, consummatory discourse $i s$ the response to a crisis (Cherwitz \& Zagacki, 1986). These types of speeches are intended to "show the U.S., as well as the world community, that enemy attacks were hostile and unprovoked, and that despite such aggression the U.S. will not respond in kind, for to do so would justify violence" (Cherwitz \& Zagacki, 1986, p. 309). 
During Reagan's 1983 address, he stated that there was “absolutely no justification, either legal or moral, for what the Soviets did" and that the act was one of "barbarism, born of a society which wantonly disregards individual rights and the value of human life" (Reagan, 1983). However, these speeches also serve as a warning that "future occurrences of violence will not go unanswered" (Cherwitz \& Zagacki, 1986, p. 309). The second half of Reagan's speech explains a way for the Soviets to make amends for their crime, by joining in on an international protective measure to make flight safer. This seems to serve as an ultimatum to join or pay the consequences.

There are rhetorical constructs that have been found to be important in presidential rhetoric from a charismatic perspective. Some of these include collective focus, temporal orientation, followers' worth, similarity to followers, values and moral justification, tangibility, action and adversity — all of which are defined by researchers Davis and Gardner (2012). There is research to suggest that rhetoric is more heavily used after a national crisis as opposed to prior to it if the event is expected or suspected (Davis \& Gardner, 2012). Presidents use their ethos, or credibility and ethical appeal, "to create 'crisis' situations" (Dow, 1989, p. 294) and handle them accordingly. According to Windt (1983), presidents have three main tactics for delivering crisis news, including using new facts that define the situation as a crisis, a "melodramatic comparison between the pure motives of the United States and the evil motives of the enemy" (Windt, 1983, pp. 127-131) and a shift from the issue to the policy the president has provided in response, for which he or she wants support.

Word choice is perhaps the most obvious and easily identifiable aspect of rhetoric. Roosevelt and Reagan (as well as many other presidents) were knowledgeable about creating a community among those who heard their words. The concept of "you" versus "us" is simple yet 
powerful, and both presidents used it to their advantage. For example, in his D-Day prayer, Roosevelt included himself in the community by asking "God give us strength" and "impart our courage unto our sons" (Roosevelt, 1933). He managed to incorporate domestic listeners, himself and the armed forces in this community. The sense of unity that came out of this simplistic rhetorical device helped boost morale at a moment when the U.S. faced large numbers of casualties. Another powerful tool associated with word choice is repetition. In his 1941 Fireside Chat on the war with Japan, which is analyzed in this study, Roosevelt compares Japan to Germany and Italy in terms their invasions and occupations of other countries, eventually pointing out their collaboration. He leads the audience to this conclusion with calculated repetition.

In 1931, ten years ago, Japan invaded Manchukuo-without warning. In 1935, Italy invaded Ethiopia — without warning. In 1938, Hitler occupied Austria-without warning. In 1939, Hitler invaded Czechoslovakia - without warning. Later in '39, Hitler invaded Poland - without warning. In 1940, Hitler invaded Norway, Denmark, the Netherlands, Belgium and Luxembourgwithout warning. In 1940, Italy attacked France and later Greece-without warning. And this year, in 1941, the Axis Powers attacked Yugoslavia and Greece and they dominated the Balkans-without warning. In 1941, also, Hitler invaded Russia-without warning. And now Japan has attacked Malaya and Thailand - and the United States—without warning. It is all of one pattern (Roosevelt, 1941).

Choosing the right word is indispensable, and repeating the perfect word or phrase can be very compelling. The key to rhetoric is knowing how to tie each tool into the next, and Roosevelt did this by combining word choice, repetition and characterization of himself on many occasions (Houck \& Nocasian, 2002). 
Roosevelt used a rhetorical tool that is essential in a powerful presidential speechmood. He had the ability to set the tone early on in a speech and then change it (Ryan, 1979). In his inaugural speech, he spent the first half of it lamenting the state of the nation - the economy and unemployment - and he set a tone to which the audience could relate. By creating a similar state of mind for the audience (of hopelessness), he effectively created a sense of unison and camaraderie between them (Houck \& Nocasian, 2002). He took listeners in and then subtly changed the mood by reminding Americans that they still had things to be thankful for and that if they worked together, their future could be bright. During this speech, Roosevelt also revealed his ability to characterize himself. In the speech he alludes to the greatness of American forefathers, promises not to repeat the mistakes of past politicians and promises he will not commit the same fallacies (Roosevelt, 1944). Lending to the sense of unity he created with his tone, he gave himself a grandfatherly quality that made him seem wise and inspired Americans (Houck \& Nocasian, 2002).

Many patterns have been witnessed across the board with the 44 presidents of the United States. According to Emrich, Brower, Feldman \& Garland (2001), the relationship between charisma and image-based rhetoric is statistically significant and "these findings suggest that the successful articulation and enactment of a leader's vision may rest on his or her ability to paint followers a verbal picture of what can be accomplished with their help" (Emrich et al., 2001). Roosevelt was well known for his use of visual metaphor. His most noteworthy metaphors came in the context of describing his vision for America (Stuckey, 2010). The metaphors he used to illustrate an exceptional and employed American people seemed to take on a life of their own, fueled by his optimism and perseverance. His rhetoric served as an instrument in lifting spirits 
and instilling patriotism (Houck \& Nocasian, 2002). In his Fireside Chat 4 on economic

progress, he compares rebuilding America's recovering economy to rebuilding a temple:

How are we constructing the edifice of recovery - the temple which, when completed, will no longer be a temple of money-changers or of beggars, but rather a temple dedicated to and maintained for a greater social justice, a greater welfare for Americathe habitation of a sound economic life? We are building, stone by stone, the columns which will support that habitation. Those columns are many in number and though, for a moment the progress of one column may disturb the progress on the pillar next to it, the work on all of them must proceed without let or hindrance (Roosevelt, 1933).

Roosevelt's visual metaphors gained power by playing off of the political culture of the time as well as the radical shift in power Roosevelt represented (Stuckey, 2010). Roosevelt as an effective communicator could make people see the grand America he envisioned and the superiority of democracy that he portrayed-especially during the Great Depression when people needed something to hold on to. In his book on Roosevelt's first inaugural address, Kiewe (2007) calls Roosevelt's rhetorical plan and his first speech the address that "saved the nation from financial collapse" (Kiewe, 2007, p. 11). Roosevelt's speeches are laced with metaphor, simile and personification - all rhetorical tools to invoke his ethos ${ }^{5}$, $\operatorname{pathos}^{6}$ and $\log ^{7}{ }^{7}$.

For example, in his 1933 inaugural address, he described the economic situation America found itself in eloquently with the phrase, "the withered leaves of industrial enterprise lie on every side" (Roosevelt, 1933). Roosevelt also used personification in his inaugural address when he famously proclaimed that "the only thing we have to fear is fear itself" (Roosevelt, 1933). The speech is also laced with military metaphors used to describe the economic war the

\footnotetext{
${ }^{5}$ Aristotle defined ethos, pathos and logos as the three ways to examine the power of text that work in conjunction with each other (Zhou \& Sloan, 2011). According to Demirdogen, ethos is the first element of Aristotle's theory of persuasion and is defined as the "charisma and the credibility of the speaker" (Demirdogen, 2010, p. 191).

${ }^{6}$ Pathos is "the mood or tone of the speech that appeals to the passions or the will of the audience" (Demirdogen, 2010, p. 192). In his writings, Aristotle's appeals were typically psychological and relied on the receivers' emotions (Demirdogen).

${ }^{7}$ Logos is an appeal to intellect or reason. Aristotle advised rhetoricians to use syllogistic arguments or enthymemes, "in which the major premise was already believed by the audience" (Demirdogen, 2010, p. 192).
} 
country was waging, such as Roosevelt referring to proposed legislation to ease the country’s pains as "lines of attack" (Roosevelt, 1933). In comparison, Reagan also demonstrated visual metaphor in his speeches to illustrate his visions for America. In his farewell address, which was taped on January 11, 1989 from the Oval Office, Reagan reiterated a visual metaphor he had used throughout his political career by quoting colonial governor John Winthrop and describing America as a "shining city upon a hill" (Reagan, 1989). He said in his mind he saw America as a “tall, proud city built on rocks stronger than oceans, windswept, God-blessed and teeming with people of all kinds living in harmony and peace; a city with free ports that hummed with commerce and creativity. And if there had to be city walls, the walls had doors and the doors were open to anyone with the will and the heart to get here" (Reagan, 1989).

Emphasis on civil religion as a popular and effective rhetorical tool is common and well researched. Reagan's political discourse, which is best known for his use of civil religious symbols and themes, was unique compared to the presidents that came before him. Through a computer-aided content analysis, researchers Lahlou, Schonhardt and Yager (2012) found that the use of "God" in speeches became empirically more frequent in Reagan's presidency than any before him. Of 25 speeches studied, 58.5 percent of Reagan's rhetoric was accounted for by civil religion — three times the size of the second largest theme, big government (Lahlou, Schonhardt \& Yager, 2012). While his rhetoric was different from previous presidents, those who came after him took his cue-civil religion has been a main rhetorical tool ever since (Lahlou, Schonhardt \&Yager, 2012). While not as well known for his use of civil religion as Reagan, Roosevelt made a noteworthy address to God that helped strengthen his rhetorical mood. During the closing of his inauguration he asked, “... in this dedication of a nation we humbly ask the blessings of God. May He protect each and every one of us. May He guide me 
in the days to come" (Roosevelt, 1933). Research shows that whether people practice religion or not, references to God in speeches create a sense of assurance-which in this case likely was part of his plan to inspire the nation and set a mood of confidence that things would get better.

Just as there have been patterns already established by researchers for all presidents, there have also been highly studied patterns, strengths and weaknesses found concerning Roosevelt and Reagan. For example, Halmari (1993) found that Reagan was a master of dichotomous political language - that is, language that managed to appeal to both political parties. Reagan was a member of the Democratic Party until the 1950s when his views shifted, and he joined the Republican Party. His understanding of the political spectrum likely influenced his rhetoric immensely (Halmari, 1993). As for Roosevelt, he created his own unique rhetorical tool. The Fireside Chats had their own structure, form and content (Ryfe, 1999). Roosevelt used the language of mass culture to close the imagined gap between the people and the president. The language and idioms used by Roosevelt to make the public feel somehow closer to him was both a rewarding and distinct tool (Ryfe, 1999). Each man is known for his own strengths and characterizing tools and language.

Debates on presidential rhetoric also continue to affect the world of research. While some studies (Conway, Gornick, Burfeind, Mandella, Kuenzli, Houck \& Fullerton, 2012) show political rhetoric decreases in complexity during election season, there is an inconsistency in research as to whether simple or complex rhetoric is more successful in politics. While some propose that simple rhetoric is key to reaching the most voters, others (Conway et al., 2012) advise that some voters perceive simple rhetoric as a weakness. However, still other research suggests that a balance of complex and simplistic rhetoric is the most effective strategy to win an election (Conway et al., 2012). This debate is significant because, according to Hammer (2010), 
the rhetoric and themes a politician uses in campaigning often transfer over into the speeches they give after being elected.

\section{Theoretical Framework}

Theory of charismatic leadership. This study is grounded in the theory of charismatic leadership (Tucker, 1968). Charismatic authority is one of sociologist Weber's (1958) three forms of authority (along with traditional authority and rational-legal authority). Weber (1958) defined charismatic authority as "resting on devotion to the exceptional sanctity, heroism or exemplary character of an individual person, and of the normative patterns or order revealed or ordained by him" (p. 245). Weber's ideas that charismatic leadership could be defined in other ways, such as with adjectives like exceptional, magical and supernatural, as well as in association with such nouns as hero and prophet, allowed Tucker to use these qualities to form his theory. The theory suggests that these qualities in a leader appeal to "followers" or audience (in this case, American citizens) and inspire a dedicated following that motivates people to forsake their own self-interests and go beyond the expected, which results in "increased follower effort, satisfaction and performance” (Davis \& Gardner, 2012, p. 919). Weber was greatly influenced by philosophers Kant, Nietzsche and even Freud. His work in developing theory on leadership in turn influenced the works of communications philosophers Habermas and Adorno.

According to Davis and Gardner (2012), these traits among followers can be used during times of crisis to encourage specific actions and promote social change when it is crucial. The combined research of Weber (1958), Shamir (1993), House (1993) and Arthur (1993) suggests that charismatic leadership emerges during times of crisis, is rooted in the relationship between the leaders and followers and produces a motivational effect on those followers so that they will "pursue the leader's vision and objectives" (Davis \& Gardner, 2012, p. 919). As such, this kind 
of relationship between leader and followers creates a strong internalization of the leader's specific values and goals and a commitment by others to see them in action. The results of research by Blight, Kohles and Meindl (2004) and Davis and Gardner (2012) suggest that crises serve as an antecedent for charismatic leadership.

"A part of the charismatic relationship between leaders and followers involves the leader's communications to the followers; this includes the delivery and presentation of the leader's speeches as well as the content of those speeches" (Blight et al., 2004a, p. 220). Previous research has demonstrated that the strength of a leader's communication style and rhetorical use of delivery and tone directly relate to the followers' perception of his or her charisma and leadership ability (Davis \& Gardner, 2012).

In a study with a focus on presidential crisis rhetoric, this theory can be applied specifically to the leaders' communication style, the content of the speeches (to communicate the leader's vision) and how rhetoric plays a role in fostering the followers' "acceptance and commitment to that vision" (Davis \& Gardner, 2012, p. 920). Davis and Gardner (2012) suggest that charismatic leaders appeal to their followers through their rhetoric by utilizing devices such as allusion to history and tradition, collective identity, focus on the leader's similarities to the followers, values and moral justifications and the use of civil religious words and symbols.

Narrative paradigm theory. While the theory of charismatic leadership is the primary lens through which this study was conducted, the narrative paradigm theory served as a secondary framework through which to view presidential crisis rhetoric. The narrative paradigm theory was introduced by Fisher (1985), who based his theory on his work with rhetoric and communications and the concept that people are storytellers in their core. Because storytelling is one of the oldest and most universal forms of communications, Fisher proposed that individuals 
approach every aspect of their lives with indispensable storytelling skills and a narrative framework (Fisher, 1985). Essentially, narrative paradigm theory states that no matter what humans are doing — creating buildings or writing an epic — their creation tells a story in a construction that is universally understood; human beings experience their lives as a series of ongoing narratives. Each narrative has the characteristics of a traditional story-conflicts, characters and sections. Fisher believed that this theory explained why storytelling has shaped the most important aspects of humanity such as history and culture, both of which are taught and understood as an endless narrative. While opposition to this theory stands on the grounds that it goes against the logical arguments that explain the existence of the human world, such as scientific and philosophical approaches, Fisher said that people make their most important decisions based on history, culture and their perceptions of the status and character of others, which all lend themselves to what he calls "narrative rationality" (Fisher, 1985, p. 75).

Roosevelt's presidency as represented in the media reads as a narrative story filled with the drama of depression and war, reoccurring characters and an obvious resolution and ending. His narrative was also shaped by the content surrounding it — stories about the state of the war, which at the time likely seemed distant to Americans, updates on Hitler and his regime, harsh economic times and a call for unity by the President. It was almost as if the story needed Roosevelt — a hero for American citizens who were buried by the Depression. While Roosevelt's media narrative certainly didn't lack conflict, it occasionally did lack resolution, at least in mainstream media. Roosevelt's favor with the media sometimes made his failures less central to the overall story (Winfield, 1990). However, his enemies (conservatives, editorialists, etc.) made up for this lack of conviction. Narrative paradigm theory helps in understanding the gradual change in the media's characterization of Roosevelt as well as the analysis of his rhetoric. While 
his story is embedded in historical issues, Roosevelt's charm and confidence saved him from much (although not all) hostile media content (Winfield, 1990). These traits are a central theme in the story of Roosevelt's long presidency.

Similarly, Reagan's narrative is filled with drama and can be chronicled through both media content and his open communication with American citizens. His rhetoric helped tell his story to Americans - a story that included an assassination attempt, the tale of Iranian hostages and how they were finally freed, an explanation of an innovative new economic model and a confession and acceptance of responsibility for deals made with Iran. Both presidents seemed to embrace narrative as both a necessity to connect with the American people and a rhetorical tool to give their messages potency. Thus, understanding a person's "story" leads to better understanding the person, his or her tactics and intents.

This study begins to fill in a gap in existing literature by exploring presidential crisis rhetoric. According to Medhurst (2012), looking at presidential rhetoric with a world view is important because America is a superpower that has substantial influence around the globe. The words the American president speaks do not only affect the citizens of the United States but also the people around the world. The United States is often looked to as "a partner for peace and prosperity" (Texture of the World, 2012). When there is a crisis in America, it is world news. This is a meaningful theme in the speeches of almost every president in the nation's history. Perhaps by pinpointing the specific strategies of two masterful communicators, this study will aid future presidents in future speeches that could potentially have a vast and powerful impact in helping guide and comfort American citizens, be a key tool of future presidential speech writers or become valuable knowledge for the informed citizen. 


\section{RESEARCH QUESTIONS}

This thesis seeks to find if there were similar or different rhetorical devices or strategies used by Roosevelt and Reagan during times of crisis. Both presidents have been historically recorded as being influential and effective communicators who were faced with great crises during their time in office, and each represents a different political party and primary medium through which they communicated. Therefore, this study seeks to answer the following research questions:

RQ 1: What rhetorical similarities, if any, are used in speeches given by presidents Franklin Roosevelt and Ronald Reagan during times of crisis?

RQ 2: What rhetorical devices are different, if any, in speeches given by presidents Franklin Roosevelt and Ronald Reagan during times of crisis?

RQ3: What are the rhetorical signifiers, if any, that Reagan studied Roosevelt's speeches?

RQ4: How do Roosevelt and Reagan's differing politics play a role in their rhetorical differences?

RQ5: In what way, if any, do crises influence a use of rhetoric that is different than typical presidential speech? 


\section{METHOD}

To answer the proposed research questions, a textual analysis of speeches made by Roosevelt and Reagan in times of crises during their respective presidencies was conducted as an exploratory approach. According to Rosenthal, Charles \& t'Hart, (1989), a crisis is defined as “a serious threat to the basic structures or the fundamental values and norms of a system, which under time pressure and highly uncertain circumstance necessitates critical decisions" (p. 10). Members of the system in question must perceive a serious and credible threat as a "requisite feature of all crisis events" (Seeger, Sellnow \& Ulmer, 2003, p. 8). Crises are defined by a set of characteristics outlined by Heath and Millar (2004) and include the cause, locus of responsibility, emergency response, size, length and urgency of the crisis. "However, urgency and surprise set the crisis apart, and thus make it a dynamic process that disturbs the status quo" (Davis \& Gardner, 2012, p. 920). To choose the speeches, the researcher looked at all crises that took place between 1932 - 1945 and 1982 - 1989 and found three from each presidency that best fit the description given by Rosenthal et al. (2001). The researcher looked for parallels in the two presidencies and chose speeches that lent themselves to comparison. These parallels include each president's first inaugural address (essentially, times of domestic crisis), economic crises and foreign crises. Transcripts of these speeches were obtained from the Miller Center's

Presidential Speech Archive online. The following speeches were chosen:

Roosevelt's first inaugural address: March 4, $1933^{8}$

Reagan's first inaugural address: January $20,1981^{9}$

\footnotetext{
${ }^{8}$ Roosevelt's first inaugural address was given on March 3, 1933, the last time an inaugural speech was given in March before the terms of the Twentieth Amendment changed the inaugural date to January 20. The speech was given on the East Portico of the United States Capitol and the oath of office was administered by Chief Justice Charles Evan Hughes. Raymond Moley, a member of Roosevelt's "Brain Trust" during his first presidential campaign is credited with writing most of this address and claimed to have coined the term "New Deal" (Britannica) and the transcript contains 1,897 words. It was broadcasted on several radio stations (Miller Center).

${ }^{9}$ Reagan's first inaugural address was given on January 20, 1981 from a platform erected on the West Front of the United States Capitol building. The oath of office was given by Chief Justice Warren E. Burger. Reagan wrote the speech himself, and the transcript contains 2,425 words. The speech was broadcast live on radio and television, and
} 
Roosevelt's Fireside Chat 4 on economic progress: October 22, $1933^{10}$

Reagan's Address on the Program for Economic Recovery: April 28, $1981^{11}$

Roosevelt's Fireside Chat 19 on the war with Japan: December 9, $1941^{12}$

Reagan's Address to the Nation on Iran-Contra: March 4, $1987^{13}$

In each situation represented by the chosen speeches, basic societal structures (the economy, bank operations, production, etc.) were under pressure and changes had to be made to the norms of the American system in order to cope. For example, when American entered World War II after the bombing of Pearl Harbor, day-to-day production operations were halted in favor of a wartime economy. These types of serious changes are what qualify these instances as crises as defined by Rosenthal et al. (2001).

Because of the specificity of defining times of crises, a textual analysis approach was most beneficial, as it lends itself to the ability to choose texts without using any type of sampling. "The goal of textual analysis is to determine the meaning of the messages that are embedded in text" (Zhou \& Sloan, 2011, p. 307). While other types of methodology usually require content to be chosen systematically or with a specific type of sampling frame, textual analysis allows content to be chosen with the researcher's judgment or a purposeful sample; the content is chosen because it possesses "a characteristic of interest to the researcher and addresses

as the president was delivering the address, 52 American hostages in Iran who had been held captive for 444 days were released (Peters \& Woolley, 1999).

${ }^{10}$ Roosevelt's fourth Fireside Chat was given on October 22, 1933 in regards to economic progress and various New Deal Agencies. The transcript contains 2,712 words, and the speech was broadcast via radio.

${ }^{11}$ Reagan's address on the program for economic recovery was given on April 28, 1981 from the House Chamber at the Capitol during a joint session of Congress. A brief introduction was given by Thomas P. O’Neill, Jr. Speaker of the House of Representatives. The speech transcript contains 2,416 words and was broadcast live on radio and television (Reagan Presidential Library).

${ }^{12}$ Roosevelt's Fireside Chat 19 on the war with Japan was given on December 9, 1941; just two days after Japan attacked Pearl Harbor. The speech was broadcast via radio and the transcript contains 3,052 words. It is worth noting that the longest studied speech was given after arguably the biggest crisis; this is important to the study of presidential crisis rhetoric. Three days after this speech was given, Japan's allies, Germany and Italy, both declared war on the United States.

${ }^{13}$ Reagan's address to the nation on the Iran-Contra affair was given on March 4, 1987 and was broadcast live on nationwide radio and television from the Oval Office (Reagan Presidential Library). The speech transcript contains 1,889 words. 
the research question" (Zhou \& Sloan, 2011, p. 308). Because of the subjective nature of determining the meaning of a text, Zhou and Sloan do not call for secondary readers or coders.

After narrowing down the crises and choosing specific speeches to analyze, the next step in performing the textual analysis was operationalizing terms related to rhetoric and conceptualizing how to measure their occurrence to perform a comparison and contrast of Roosevelt and Reagan. Operationalizing allows the researcher and the audience to clearly understand the concepts being measured (Zhou \& Sloan, 2011). In turn, conceptualization is naming the previously defined concepts and looking at how they form key themes, ideas and patterns within the texts. It was important to utilize the literature review and, if possible, to use previous research to operationalize terms while also keeping in mind the research questions to keep concepts specific and on topic. Because critical and cultural studies often rely solely on descriptive analysis, nailing down these definitions and concepts was crucial. This study looked for the predefined rhetoric devices civil religion, collective focus, consummatory discourse, conversational speech, democratic rhetoric, imagery, justificatory discourse and similarity to followers, which can be found below in Table 1, as well as basic rhetorical elements such as anecdote, characterization, ethos, logos, metaphor, mood, pathos, personification, repetition, simile and word choice.

Table 1: Operationalization of Rhetorical Devices

\begin{tabular}{|l|l|}
\hline \multicolumn{1}{|c|}{ Rhetorical Device } & \multicolumn{1}{c|}{ Definition } \\
\hline Civil religion & $\begin{array}{l}\text { "The traditional symbolic dimension of American } \\
\text { nationalism" (Hammer, 2012, p. 2) or the "collection } \\
\text { of beliefs, symbol and rituals with respect to sacred } \\
\text { things and institutionalized in a collectivity" (Bellah, } \\
1976, \text { p. 8). }\end{array}$ \\
\hline Collective focus & $\begin{array}{l}\text { "Singular nouns connotating plurality; these words } \\
\text { refer to social groupings, task groups, and } \\
\text { geographical entities" (Davis \& Gardner, 2012, p. }\end{array}$ \\
\hline
\end{tabular}




\begin{tabular}{|c|c|}
\hline & 931). \\
\hline Consummatory discourse & $\begin{array}{l}\text { "Consummatory messages endeavor to show the } \\
\text { people of the U.S., as well as the world community, } \\
\text { that enemy attacks were hostile offenses } \\
\text { perpetrated by ruthless, savage and uncivilized } \\
\text { enemies" (Cherwitz \& Zagacki, 1986, p. 309). }\end{array}$ \\
\hline Conversational speech & $\begin{array}{l}\text { "Uses a language that engenders an intimacy } \\
\text { between the rhetor and his audience, focuses on } \\
\text { the trustworthiness of the rhetor and is highly } \\
\text { antecdotal" (Lim, 2002, p. 346). }\end{array}$ \\
\hline Democratic rhetoric & $\begin{array}{l}\text { "A rhetoric that honors the people (and their } \\
\text { visionary leader), is compassionate, inclusive and } \\
\text { egalitarian" (Lim, 2002, p. 338). }\end{array}$ \\
\hline Imagery & $\begin{array}{l}\text { "Words that evoke pictures, sounds, smells, tastes } \\
\text { and other sensations" (Emrich et al., 2001, p. 529). }\end{array}$ \\
\hline Justificatory discourse & $\begin{array}{l}\text { "Presidential remarks focus on explanation and } \\
\text { rationalization" of crises (Cherwitz \& Zagacki, 1986, } \\
\text { p. 309). }\end{array}$ \\
\hline Similarity to followers & $\begin{array}{l}\text { "Consists of words which build a sense of } \\
\text { completeness and assurance such as totalizing } \\
\text { terms, adverbs of permanence and resolute } \\
\text { adjectives" (Davis \& Gardner, 2012, p. 931). } \\
\text { Example: Everybody, fully, obvious, permanent, } \\
\text { totally unquestionably (Davis \& Gardner, 2012, p. } \\
\text { 931). }\end{array}$ \\
\hline
\end{tabular}

While textual analysis can be used as a quantitative research method by assigning terms and patterns numerical values with the use of coding, this study uses purely descriptive, qualitative data. The researcher performed five structured "reads" (Zhou \& Sloan, 2011, p. 311) of the texts and took copious notes while analyzing the content. "As content is viewed, the researcher writes down the important characteristics, patterns and themes that address the research question. It is like exploring the content to see what is meaningful within it. The idea is to find central consistencies that are apparent in most of the items being analyzed" (Zhou \& Sloan, 2011, p. 311). In the early reads, it was important for the reader to condense the content into preliminary categories and themes (Zhou \& Sloan, 2011). The researcher first read each of the selected speeches three times in their entirety, noting the use of the rhetorical terms defined in Table 1. For this particular study, the rhetorical terms studied were limited to the ones defined by prior research. The speeches were examined for the aforementioned rhetorical devices as 
well as valence and conciliatory messages. Valence and conciliatory messages were noted because they were found in each of the speeches and were made relevant by Hammer's research.

After the initial round of reads, the researcher then went back to the texts with the specific themes and categories established by the initial reads, paying particular attention to how and when these concepts are used. With these themes in mind, the speeches were read for the fourth time in pairs, comparing the two speeches in each category (domestic crises, economic crises and foreign crises). According Zhou and Sloan, this was most likely when apparent patterns would emerge, such as if the categories overlap or are dependent on each other. The researcher's notes should reflect if and when relationships were found. The fifth round of reads was to focus on finding examples and illustrations of the patterns and themes found. The examples are used as data in the results section of the study (Zhou \& Sloan, 2011).

Because texts are written and constructed by people, they are "in a sense ... an action or a process" (Zhou \& Sloan, 2011, p. 311). The understanding of texts by different people or groups is often based on cultural norms and values. For example, this study reflects that both Roosevelt and Reagan used civil religious words and symbols as a rhetorical device. The symbol of an American flag would be interpreted differently by an armed services veteran and an anti-war protestor or someone from another country (Zhou \& Sloan, 2011). As a researcher, it is important to keep one's own cultural norms in mind, while not letting them bias the outcome. However, a certain level of human bias is unavoidable, especially when utilizing descriptive data versus quantitative data. Texts can also be ambiguous, so one reader can interpret multiple meanings from the same text. The power of a text often guides audience interpretation. In using textual analysis, it is important to note the concepts of ideology and hegemony (Zhou \& Sloan, 2011). 
Various studies support the use of textual analysis as a way to provide valuable critical and cultural information. For example, in her study, Andrews (2011) uses a textual analysis of nine significant speeches given by Obama to determine how he addresses the issue of his own race to the American public. The analysis seeks to find patterns of how often and in what manner Obama spoke about race as well as the race related rhetoric he used to help him secure the presidency. By conducting thorough reads of these speeches, Andrews found that when addressing race, Obama used valence messages, conciliatory messages and imagery to relate his intended message to a modern audience (Andrews, 2011, p. 12). In the methods section of this study, Andrews created a table of operationalized rhetorical terms, whose definitions she found by reading previous literature on this topic. In a similar way, this study operationalizes rhetorical terms (using Andrews' study as well as others), notes themes, patterns and relationships and illustrates those relationships with descriptive data.

A textual analysis of speeches delineates rhetoric and the fact that there is an "enduring importance" (Foss, 1996, p. 7) to the speeches even after the rhetor is gone and the event or occasion past. Generic criticism seeks to reveal similarities in rhetorical patterns across comparable situations. It operates under the assumption that "certain types of situations provoke similar needs and experiences among audiences and thus call for particular kinds of rhetoric" (Foss, 1996, p. 225) — in this case, crisis situations. The generic critic can analyze parallel situations across time periods and locations and examine their similarities and the rhetorical responses to those situations. While this study will utilize a textual analysis, the goals are the same - to understand how crisis rhetoric is comparable across time, political parties and speakers because it is provoked by crises and pertains to the experience of the audience. 
A textual analysis informs the way the speeches are chosen and the way they are reviewed, and once the textual analysis is complete and the media message has been deconstructed, the research needs to be considered by its social, political and cultural implications (Zhou \& Sloan, 2011). According to Zhou and Sloan, "content is seen as one mechanism that helps people understand our social world" (p. 307). This, among many other reasons, is why this textual analysis of crisis speeches by Roosevelt and Reagan serves a broader purpose of helping to understand and interpret the contemporary political and social world.

\section{RESULTS}

During this study, the researcher performed five reads of the six chosen speeches. This allowed the researcher to grasp the topic, mood and rhetorical devices of each speech and also to make observations on the style and tendencies of each president. After taking notes on each individual speech, the researcher read the speeches in pairs, comparing the two speeches within each of the three themes (domestic crises, economic crises and foreign crises). While taking copious notes and analyzing content, the researcher identified important characteristics, patterns and themes that addressed the research questions and found central consistencies to formulate into categories. Specific reads were also conducted to look for the pre-defined terms in Table 1 as well as valence and conciliatory messages.

In regard to RQ1, the initial rounds of reads found that Roosevelt consistently uses imagery, military metaphors, repetition and characterization, while Reagan's speeches consistently utilize consummatory, justificatory and conciliatory discourse. There is a distinct difference in the tone each president uses, although each seems effective in its own right. Roosevelt's rhetorical voice is a combination of his credibility and authority (ethos) and an 
emotional appeal used to bring the nation together (pathos). His pathos is accomplished with vivid language that evokes sensory details. For example, in his first inaugural address, Roosevelt successfully aligns himself with the audience (similarity to followers, Table 1) by building an elaborate metaphor that is easily evoked into a mental image:

In such a spirit on my part and on yours we face our common difficulties. They concern, thank God, only material things. Values have shrunken to fantastic levels; taxes have risen; our ability to pay has fallen; government of all kinds is faced by serious curtailment of income; the means of exchange are frozen in the currents of trade; the withered leaves of industrial enterprise lie on every side; farmers find no markets for their produce; the savings of many years in thousands of families are gone.

In a single paragraph, Roosevelt manages to utilize visual metaphor, similarity to followers and civil religion while addressing the heart of the domestic crisis. However, Reagan's rhetorical voice is a combination of logic to support his claims (logos) and pathos. His emotional appeals evoke a sense of kindness and brotherhood, such as the opening of his 1987 address to the nation on Iran-Contra:

I've spoken to you from this historic office on many occasions and about many things. The power of the Presidency is often thought to reside within this Oval Office. Yet it doesn't rest here; it rests in you, the American people, and in your trust. Your trust is what gives a President his powers of leadership and his personal strength, and it's what I want to talk to you about this evening.

His speech uplifts democracy, unites listeners and offers valence messages on the values that are important to Reagan as a conservative politician - the trust of his constituents, the power of democracy and American symbols such as the Oval Office, the flag, etc. Reagan's rhetoric often encourages listeners to step outside of their separate experiences in favor of experiencing his speech as united Americans. This is demonstrated in the passage above as well as his first inaugural speech in which he speaks of abolishing special interest groups in favor of "we the 
people," the interest group that "knows no sectional boundaries or ethnic and racial divisions" and "crosses political party lines" (Reagan, 1981).

Clear patterns emerged during the first round of reads. Each president creates for himself a common array of greetings and closings, which for Roosevelt includes opening with "My fellow Americans" or, in the case of his Fireside Chats, simply starting or ending the speech without a formal greeting or closing, creating the form of conversational speech that appealed to so many and made his Fireside Chats so memorable. Reagan, however, begins his speeches with very formal greetings, usually either "My fellow Americans" or an address to prestigious members in attendance, such as senators, former presidents, the Speaker of the House, etc. He ends the three speeches analyzed in this study with "God bless you, and thank you" (inaugural), "Good night, and God bless you" (Iran-Contra) and "Thank you. Good night" (economic recovery). Also, similar and reoccurring valence messages were present in each of the six speeches. These include expressions on the hardships of the working man, the uplifting of democracy and inclusive language ("us" versus “you”). These examples help answer RQ1 and RQ2, suggesting that each president has a unique rhetorical style with independent rhetorical niches but also that characteristic presidential crisis rhetoric combined with each presidents' natural communication skills provided common rhetorical themes, such as conciliatory messages, conversation speech styles and democratic rhetoric.

When Reagan was a college student and young actor, he enthusiastically supported Roosevelt's liberal policies. Even after he switched parties, Reagan's admiration for Roosevelt can be seen in his regularly scheduled radio broadcasts, which started in 1982. These addresses, which took place on Saturdays, were the first of their kind since Roosevelt (Hopkins, 2013). In years after his presidency, Reagan was quoted as saying that he idolized Roosevelt. 
He'd entered the White House facing a national emergency as grim as any the country has ever faced and, acting quickly, he had implemented a plan of action to deal with the crisis. During his Fireside Chats, his strong, gentle, confident voice resonated across the nation with an eloquence that brought comfort and resilience to a nation caught up in a storm and reassured that we could lick any problem. I will never forget him for that (Reagan, 1992).

During his governorship, Reagan had a radio series called the "Viewpoint Commentary," during which he tried to speak to reach Democrats (who then controlled the California state legislature) and build partisan support for his policies. He got the idea from Roosevelt, who "left an indelible mark" on him during the Depression (Auer, 1992, p. 169). Reagan said that he hoped to get public opinion on his side "by going on television or radio and telling the people what was going on in Sacramento and what we were trying to do about it” (Reagan, 1992). Roosevelt's influence is more easily seen in Reagan's earlier speeches, before he was elected to the presidency. Reagan wrote all of his own speeches before he became president, spending hours editing them until he was satisfied. However, he soon realized after his inauguration that his schedule did not allow time for his in-depth process and accepted help from the White House staff (Hopkins, 2013).

There are several similarities in their rhetorical style that suggest that Reagan studied Roosevelt's speeches, his Fireside Chats in particular. This relationship has been hinted at and documented by researchers and can be found in literature such as Reagan and Public Discourse in America, edited by Michael Weiler and W. Barnett Pearce. Both Roosevelt and Reagan made each speech very specific, giving them a clearly defined topic that was stated early on, followed by a plan of action (Hopkins, 2013). This was often accomplished by using signposts to ensure the audience could follow the speech. Similar to Roosevelt's first Fireside Chat in March 1933, which begins with, "I want to talk for a few minutes with the people of the United States about banking," (Roosevelt, 1933), Reagan gave his speeches a concise thesis statement. In his 1981 
address on the program for economic recovery, Reagan follows his typical greeting with, "I have come to speak to you tonight about our economic recovery program” (Reagan, 1981).

Another similarity Roosevelt and Reagan share is rhetoric that purposely appeals to a wide variety of ethnicities, religions and other social groups. Roosevelt appealed to a formidable coalition of followers that included low-income, religious minorities, African-Americans, union members and immigrant groups (Miller Center). Their rhetorical strategy was inclusion; that is, speaking to each and every person as simply an American. Kathleen Jamieson wrote:

Reagan knows that he is addressing individuals - perhaps two or three in a family group around the television set, and not a vast audience in a great hall. Consequently, his style becomes conversational and intimate, dramatizing and storytelling, self-disclosing, personal and intense, and keying upon memorable phrases, uttered whenever possible in memorable political settings. Not all of his successors who try the same approach will find it working well for them. After all, Reagan was an actor, reading lines (Auer, 1992, p. 115).

Reagan emulated Roosevelt yet again with his simple, direct rhetoric (Sigelman \& Whissel, 2002). According to Sigelman and Whissell, although the president of the United States may be the most powerful person in the world, when Reagan spoke to his fellow Americans, he sounded like he was simply one of them (2002). Reagan worked closely with his speech writers to ensure that he was always in control of his public addresses. He had a set of rules that he wanted them to abide by when writing, which included his preference for short sentences, not using a two syllable word if a one syllable word could replace it and always giving an example to illustrate a point (Hopkins, 2013). He was able to take words written by others and make them sound like his own. ${ }^{14}$

\footnotetext{
${ }^{14}$ The researcher could not find concrete sources or documentation on which presidential speechwriters helped to write each of the analyzed speeches. However, each president has ownership over his speeches. While some research seeks to trace the origins of famous phrases and ideas, once a speech is given and the president lends his authority and voice to the words, they are credited to him or her (Schlesinger, 2008).
} 
Reagan's use of signposts, conciliatory messages intended to reach a wide demographic of listeners and direct, conversational speech are all rhetorical signifiers that support the idea that he studied Roosevelt's speeches and help to answer RQ3. It also brings this research full circle. As suggested by Hammer (2010), President Obama also attempted to rhetorically appeal to the largest coalition of listeners, which he may have done by studying Reagan's rhetorical style. In a conference paper submitted to the National Communication Association in 2008, Jonathan Riehl suggests that by studying and adopting Reagan's "unwavering optimism," "heroic or mythic reading of American history," "explicit rejection of political and social categories such as race" and "synechdocal linkage of the candidate himself with American idealism or exceptionalism," Obama has successfully implemented Reagan's ability to capture a broad spectrum of the American audience (Riehl, 2008, Abstract). The notion that Obama would want to emulate Reagan given their distinct and contradictory political ideologies lends itself to the idea of Reagan as "The Great Communicator." While it is clear that Reagan admired and studied Roosevelt, he also referenced many other U.S. presidents, including Abraham Lincoln and George Washington. His use of illusion is yet one more rhetorical tool used to ignite public stream-of-consciousness.

After the initial round of reads, the researcher then went back to the texts with the established themes, categories and similarities, paying particular attention to how and when these concepts are used. According to Zhou and Sloan (2011), this was most likely when apparent patterns would emerge, such as if the categories overlap or are dependent on each other. While the use of hermeneutic analysis traditionally has been reserved for religious texts, its application as a type of textual analysis is beneficial here (Stanford, 2005). During the fourth and fifth reads of each speech, deeper meanings of the texts began to surface, especially in regard to the theme of 
democratic speech. The researcher found that in times of crisis, there is a huge distinction in the way Roosevelt and Reagan's differing political affiliations influenced the way they spoke about the use of the Constitution and their executive power to address crises. Roosevelt spoke often of a liberal use of Constitutional power to best serve citizens during the Great Depression.

"Our Constitution is so simple and practical that it is possible always to meet extraordinary needs by changes in emphasis and arrangement without loss of essential form," he spoke in his first inaugural address (Roosevelt, 1933). In the speech he continues speaking about his “constitutional authority" and, as became characteristic of his time in office, asked Congress to grant him "broad Executive power to wage a war against the emergency, as great as the power that would be given to me if we were in fact invaded by a foreign foe" to meet domestic crises (Roosevelt, 1933). Reagan's conservative politics became well-known via his many speeches and television appearances. In his own inaugural speech, Reagan makes it clear that he intended to "curb the size and influence of the Federal establishment and to demand recognition of the distinction between the powers granted to the Federal Government and those reserved to the States or to the people." Thus, Roosevelt, who was arguably president during a much more tense and desperate time in American history, used rhetoric of supreme authority and extended powers to reassure the nation that he would see them into more prosperous times while Reagan reassured citizens that he would return the power to them. While on the surface both presidents were addressing crisis, it is possible that they were also seeking affirmation and support for the way they interpreted and used the Constitution as a source of power. These opposing rhetorical strategies both seem to be incredibly effective and help to answer RQ4.

Presidents use rhetoric to consistently ease citizens' minds about the woes of the world, both domestic and foreign. During times of peace and prosperity, little rhetoric is needed to keep 
constituents happy. During times of mild emergency, there is likely only a small percentage of Americans actually following the goings-on of the political climate. However, during times of crisis, people are certainly more aware that there is an issue, and they may want extra assurance of their safety and security (whether physical or financial). This forces politicians, and the president in particular, to employ rhetoric that soothes the collective mind, employ rhetoric that offers an aggressive attitude of consummatory discourse (such as Roosevelt's military metaphors) or employ rhetoric that inspires an element of charisma for the president to find support for his or her legislation or intended response to the crisis at hand. While it is likely that rhetoric is more aggressively used during times of crisis, the research done for this thesis does not find support for answering RQ5. To find evidence and specific examples of how presidential crisis rhetoric differs from campaign rhetoric or rhetoric used in daily presidential speeches, a more in-depth study would need to be conducted.

The final stages of the readings focused on finding examples and illustrations of the patterns, themes and devices. These examples can be found below in Table 2 .

Table 2: Examples of Rhetorical Devices

\begin{tabular}{|l|l|}
\hline \multicolumn{1}{|c|}{ Rhetorical Device } & \multicolumn{1}{|c|}{ Examples } \\
\hline Civil religion & $\begin{array}{l}\text { "In this dedication of a Nation we humbly ask the } \\
\text { blessings of God. May He protect each and every } \\
\text { one of us. May He guide me in the days to come" } \\
\text { (Roosevelt's first inaugural address). } \\
\text { "We are a nation under God, and I believe God } \\
\text { intended for us to be free" (Reagan's first inaugural } \\
\text { address). }\end{array}$ \\
\hline Collective focus & $\begin{array}{l}\text { Roosevelt's various references to "the Nation" in } \\
\text { Fireside Chat 4 on economic progress. }\end{array}$ \\
\hline Consummatory discourse & $\begin{array}{l}\text { "Powerful and resourceful gangsters have banded } \\
\text { together to make war upon the whole human race" } \\
\text { (Roosevelt Fireside Chat 19). }\end{array}$ \\
\hline
\end{tabular}




\begin{tabular}{|c|c|}
\hline & $\begin{array}{l}\text { "As for the enemies of freedom, those who are } \\
\text { potential adversaries, they will be reminded that } \\
\text { peace is the highest aspiration of the American } \\
\text { people. We will negotiate for it, sacrifice for it; we } \\
\text { will not surrender it, now or ever" (Reagan's first } \\
\text { inaugural address). }\end{array}$ \\
\hline Conversational speech & $\begin{array}{l}\text { "I'd like to say a few words directly to all of you and } \\
\text { to those who are watching and listening tonight, } \\
\text { because this is the only way I know to express to } \\
\text { all of you on behalf of Nancy and myself the } \\
\text { appreciation for your messages and flowers and, } \\
\text { most of all, your prayers, not only for me, but for } \\
\text { those others who fell beside me. The warmth of } \\
\text { your words, the expression of your friendship, and } \\
\text { yes, love, meant more to us than you can ever } \\
\text { know" (Reagan's address on the program for } \\
\text { economic recovery). }\end{array}$ \\
\hline Democratic rhetoric & $\begin{array}{l}\text { "Because, in every step which your Government is } \\
\text { taking we are thinking in terms of the average of } \\
\text { you- in the old words, 'the greatest good to the } \\
\text { greatest number' ..." (Roosevelt's Fireside Chat 4). } \\
\text { "So, as we begin, let us take inventory. We are a } \\
\text { nation that has a government-not the other way } \\
\text { around. And this makes us special among the } \\
\text { nations of the Earth. Our government has no power } \\
\text { except that granted it by the people. It is time to } \\
\text { check and reverse the growth of government, } \\
\text { which shows signs of having grown beyond the } \\
\text { consent of the governed" (Reagan's first inaugural } \\
\text { address). }\end{array}$ \\
\hline Imagery & $\begin{array}{l}\text { "... the means of exchange are frozen in the } \\
\text { currents of trade; the withered leaves of industrial } \\
\text { enterprise lie on every side ..." } \\
\text { "... that if we go forward, we must move as a } \\
\text { trained and loyal army willing to sacrifice for the } \\
\text { good of a common discipline ... This I propose to } \\
\text { offer, pledging that the larger purposes will bind us } \\
\text { all as a sacred obligation with a unity of duty } \\
\text { hitherto evoked only in time of armed strife." } \\
\text { (Roosevelt's first inaugural address). }\end{array}$ \\
\hline Justificatory discourse & $\begin{array}{l}\text { "Now, what should happen when you make a } \\
\text { mistake is this: You take your knocks, you learn } \\
\text { your lessons, and then you move on. That's the } \\
\text { healthiest way to deal with a problem. This in no } \\
\text { way diminishes the importance of the other } \\
\text { continuing investigations, but the business of our } \\
\text { country and our people must proceed. I've gotten } \\
\text { this message from Republicans and Democrats in } \\
\text { Congress, from allies around the world, and-if } \\
\text { we're reading the signals right-even from the } \\
\text { Soviets. And of course, l've heard the message } \\
\text { from you, the American people. You know, by the } \\
\text { time you reach my age, you've made plenty of } \\
\text { mistakes. And if you've lived your life properly-so, }\end{array}$ \\
\hline
\end{tabular}




\begin{tabular}{|l|l|}
\hline Similarity to followers & $\begin{array}{l}\text { you learn. You put things in perspective. You pull } \\
\text { your energies together. You change. You go } \\
\text { forward" (Reagan's address to the nation on Iran- } \\
\text { Contra). }\end{array}$ \\
\hline $\begin{array}{l}\text { "The permanent welfare and security of every class } \\
\text { of our people ultimately depends on our attainment } \\
\text { of these purposes" (Roosevelt's Fireside Chat 4). } \\
\text { "Well, we have much greatness before us. We can } \\
\text { restore our economic strength and build } \\
\text { opportunities like none we've ever had before" } \\
\text { (Reagan's address on the program for economic } \\
\text { recovery). }\end{array}$ \\
\hline
\end{tabular}

\section{DISCUSSION \& IMPLICATIONS}

The purpose of this study was to examine specific rhetorical similarities and differences that exist between presidents Franklin Roosevelt and Ronald Reagan and how each president used his rhetoric to address and mediate crises. The research conducted was able to answer four out of five of the research questions, with no conclusive answer found for RQ5. Rhetorical similarities such as conversational and democratic speech (RQ1) and rhetorical differences (RQ2) such as Roosevelt's imagery and Reagan's use of Aristotle's pillars of persuasion (ethos, pathos and logos) were found and examples listed in Table 2. Reagan's repetitive use of concise signposts, conciliatory messages and formatted radio broadcasts helped answer RQ3, which suggests that Reagan studied Roosevelt's speeches. After the five reads of each speech were complete, deeper themes of executive power and Constitutional authority were noted to help answer RQ4, which sought to explore the ways Roosevelt and Reagan's political affiliations affect their rhetoric. It was determined by the researcher that perhaps further study and analysis was needed to effectively address RQ5, which sought to examine the difference between presidential crisis rhetoric and day-to-day presidential speech and found none. However, the research questions helped to link this study to present day politics by leading the researcher to 
see how presidents deemed exceptional communicators likely study one another's speeches to produce similar results. It has already been suggested that Obama will be reflected upon historically as an able orator and that he indeed studied predecessors he deemed effective as well.

The findings of this study suggest that both Roosevelt and Reagan utilized specific and purposeful rhetoric meant to explain crises, comfort and unite Americans, implement and rationalize policies for change and convince audiences that relief would come. In a broad view, this study may draw important conclusions about presidential crisis rhetoric that could be used by future politicians to handle and address crises efficiently and effectively. For example, future presidential speech writers may want to utilize the rhetorical devices shown in Tables $1 \& 2$, study the speeches of previous effective communicators and approach party politics in a way that appeals to the widest coalition of listeners.

\section{Limitations \& Future Study}

Although this study provides insight on presidential crisis rhetoric concerning Roosevelt and Reagan, it has limitations that future research should consider. Textual analyses provide purely descriptive data. This type of analysis is effective for describing text and content; however, primary research using methodologies such as surveys, interviews and coding to analyze data or a mixed-method approach would also help reveal patterns and overcome researcher bias. Textual analysis lends a lot of discretion to the researcher. Historical documents themselves are not always a reflection of reality. While textual analysis is used to "describe, interpret and evaluate" the characteristics of a message and determine how the author conveyed meaning to an audience (Morris, 2004, p. 163), it allows the reader to interpret the meaning of an entire work by finding meaning in smaller pieces of the work, such as language units. Interpretation is left entirely to the researcher by conducting critical reads (Morris, 2004). 
This leaves out critical components to evaluating the text, such as delivery and audience response. When performing a textual analysis, the researcher focuses solely on the text, or words on a page, without considering the oral delivery, the medium (radio, television, etc.) through which the text was heard or viewed or the responses of the intended audience and the media. Also, the speech transcripts used in this study contain the published texts of each speech, not the actual words spoken, which may be slightly different (Miller Center). Qualitative analyses can also be limited by the availability of material.

Future research on this topic could explore the crisis rhetoric of other presidents, especially those less well known for gifted speech, or analyze the speeches by studying the speech writers rather than the presidents. By using a different approach, such as generic criticism or media content analysis of speech coverage, future researchers could incorporate oral delivery and audience response to produce a broader understanding of crisis rhetoric. While this textual analysis does not fully determine the meaning of these texts, it does provide important findings for the genre of presidential crisis rhetoric and supports the findings of other researchers, such as Davis \& Gardner (2012) by suggesting that crises are an antecedent for charismatic leadership. This study serves as an exploratory approach to understanding presidential crisis rhetoric; however, much research remains to fully understand how presidents use rhetoric to respond to or control crisis situations. 


\section{REFERENCES}

Aaron, B. \& Rockoff, D. (1994). “The Attempted Assassination of President Reagan: Medical Implications and Historical Perspective. " JAMA: The Journal of the American Medical Association, 1689-1693.

"Address Before a Joint Session of the Congress on the Program for Economic Recovery." Ronald Reagan Presidential Library \& Museum. National Archives and Records Administration, n.d. Web.

Andrews, A. D. (2011). A Textual Analysis of Barack Obama's Campaign Discourse Regarding His Race. Butler University Digital Commons.

Aristotle. Rhetoric. Trans. W. Rhys Roberts (1994). Internet Classics Archive.

Auer, J. (1992). “Acting like a president; or, what has Ronald Reagan done to political speaking?” In M. Weiler \& W. Pearce (Eds.), Reagan and Public Discourse in America. Tuscaloosa, AL: The University of Alabama Press.

Barber, J.D. (1972). The Presidential Character: Predicting Performance in the White House. Englewood Cliffs, NJ: Prentice-Hall.

Black, E. (1965). Rhetorical Criticism: A Study in Method. Madison, Wisconsin: The University of Wisconsin Press.

Blight, M. C., Kohles, J. C., \& Meindl, J. R. (2004a). Charisma under crisis: Presidential leadership, rhetoric, and media responses before and after the September 11 th terrorist attacks. The Leadership Quarterly, 15, 211-239.

Boal, K. B., \& Bryson, J. M. (1988). Charismatic leadership: A phenomenological and structural approach. In J. G. Hunt, B. R. Baliga, H. P. Dachler \& C. A. Schriesheim (Eds.), Emerging leadership vistas (pp. 11-28). Lexington, MA: Lexington Books. 
Braden, W. W., \& Brandenburg, E. (1955). Roosevelt's Fireside Chats. Speech Monographs, 22(5), 290.

Casaregola, V. (1992). "Declassicizing" Ancient Rhetoric: Toward a Reconstructed Rhetoric of Oral Performance. [S.1.]: Distributed by ERIC Clearinghouse.

Cherwitz, R. A., \& Zagacki, K. S. (1986). Consummatory Versus Justificatory Crisis Rhetoric. Western Journal Of Speech Communication: WJSC, 50(4), 307-324.

Conger, J. A., \& Kanungo, R. N. (1987). Toward a behavioral theory of charismatic leadership in organizational settings. Academy of Management Review, 12, 637-647.

Conger, J. A., Kanungo, R. N., \& Menon, S. T. (2000). Charismatic leadership and follower effects. Journal of Organizational Behavior, 21, 747-767.

Conway, L., Gornick, L., Burfeind, C., Mandella, P., Kuenzli, A., Houck, S. \& Fullerton, D. (2012). Does complex or simple rhetoric win elections? An integrative complexity analysis of U.S. presidential campaigns. Political Psychology, 33(5), 599-618. doi:10.1111/j.1467-9221.2012.00910.x

Cook, T. D., \& Campbell, D. T. (1976). The design and conduct of quasi-experiments and true experiments in field settings. Handbook of Industrial/

“The Crist Switch: Top 10 Political Defections.” Time. Time Inc., 29 April 2009. Web. http://content.time.com/time/specials/packages/article/0,28804,1894529_1894528_18945 $\underline{18,00 . h t m l}$

Demirdogen, U. D. (2010). The Roots of Research in (Political) Persuasion: Ethos, Pathos, Logos and the Yale Studies of Persuasive Communications. International Journal of Social Inquiry, 3(1), 189-201. 
Davis, K. M., \& Gardner, W. L. (2012). Charisma under crisis revisited: Presidential leadership, perceived leader effectiveness, and contextual influences. The Leadership Quarterly, 23(5), 918-933.doi:10.1016/j.leaqua.2012.06.001

Dayan, D. \& Katz, E. (1992). Media Events: The Live Broadcasting of History. Cambridge, Massachusetts: Harvard University Press.

Dow, B. J. (1989). The Function of Epideictic and Deliberative Strategies in Presidential Crisis Rhetoric. Western Journal Of Speech Communication: WJSC, 53(3), 294-310.

Emrich, C.G., Brower, H.H., Feldman, J.M., \& Garland, H. (2001). Images in Words: Presidential Rhetoric, Charisma, and Greatness. Administrative Science Quarterly, 46, $527-557$.

Fisher, W. (1985). The Narrative Paradigm: In the Beginning. Journal of Communication, 35(4), 74-89. doi: 10.1111/j.1460-2466.1985.tb02974.x

Foss, S. K. (1996). Rhetorical Criticism: Exploration and Practice. Prospect Heights, Illinois: Waveland Press, Inc.

Freidel, F. "The Fortieth President 1981-1989." The Presidents of the United States of America,. Washington: White House Historical Association, 1982. 84-86. Print.

Freidel, F. (1982). The Presidents of the United States of America. Washington, D.C.: White House Historical Association, with the cooperation of the National Geographic Society.

Halmari, H. (1993). Dividing the World: The Dichotomous Rhetoric of Ronald Reagan. Multilingua: Journal Of Cross-Cultural And Interlanguage Communication, 12(2), 143176. doi:10.1515/mult.1993.12.2.143

Hammer, S. (2010). The role of narrative in political campaigning: An analysis of speeches by Barack Obama. National Identities, 12(3), 269-290. doi:10.1080/14608944.2010.503439 
Heath, R. L., \& Miller, D. P. (2004). A Rhetorical Approach to Crisis Communication: Management, Communication Processes and Strategic Responses. Public Relations Review (32) 367-376.

“Hermeneutics.” Stanford Encyclopedia of Philosophy. Stanford University. 2005. Web. http://plato.stanford.edu/entries/hermeneutics/

Hertsgaard, Mark. "Beloved by the Media: Ronald Reagan." The Nation Magazine 24 June 2004: n. pag. Web.

Hertsgaard, Mark. On Bended Knee: The Press and the Reagan Presidency. New York: Farrar, Straus, Giroux, 1988. Print.

Hopkins, A. (2013). “Ronald Reagan’s Presidential Radio Addresses: Themes of Unity.” Student Pulse: The International Student Journal. Web. http://www.studentpulse.com/articles/733/6/ronald-reagans-presidential-radio-addressesthemes-of-unity

Houck, D. W., \& Nocasian, M. (2002). FDR's First Inaugural Address: Text, Context, and Reception. Rhetoric \& Public Affairs, 5(4), 649-678.

Hunt, J. G., Boal, K. B., \& Dodge, G. E. (1999). The effects of visionary and crisis-responsive charisma on followers: An experimental examination of two kinds of charismatic leadership. The Leadership Quarterly, 10, 423-448.

Jamieson, K. (1988). Eloquence in an Electronic Age: The Transformation of Political Speechmaking. New York, New York: Oxford Press.

Kiewe, Amos (2007). FDR's First Fireside Chat: Public Confidence and the Banking Crisis. College Station, TX: Texas A\&M Press. 
Lahlou, S., Schonhardt-Bailey, C., \& Yager, E. (2012). Yes, Ronald Reagan's Rhetoric Was Unique_-But Statistically, How Unique?. Presidential Studies Quarterly, 42(3), 482-513.

Lim, E.T. (2002). Five Trends in Presidential Rhetoric: An Analysis of Rhetoric from George Washington to Bill Clinton. Presidential Studies Quarterly. 32, 328366.

McClure, K. (2011). The Rhetoric of Disaster: The Presidential Natural Disaster Address as an Emergent Genre. Relevant Rhetoric: A New Journal Of Rhetorical Studies, 21-15.

Morris, J. (2004). Textual Analysis in Journalism. In S. Iorio (Ed.) Qualitative Research in Journalism, 263-274. Mahwah: Lawrence Erlbaum Associates, Inc.

Noonan, P. (1990) What I Saw at the Revolution: A Political Life in the Reagan Era. New York: Random House.

"Peter M. Robinson '79." Peter M. Robinson '79. Dartmouth University, n.d. Web. 10 Sept. 2013. http://www.dartmouth.edu/ trustees/biographies/robinson.html

Perkins, F. (1946). The Roosevelt I Knew. New York: Harper \& Row.

Plato. Gorgias. Trans. W.C. Hembold. (1997). Upper Saddle River: Prentice Hall.

Ramberg, B. \& Gjesdal, K. (2013). Hermeneutics. The Stanford Encyclopedia of Philosophy. 31 March 2014. Web.

Reagan, R. W. (1981, January 20). Ronald Reagan's First Inaugural Address. Speech broadcast life on nationwide radio and television, United States Capitol Building, Washington, D.C. http://millercenter.org/president/speeches/detail/3407

Reagan, R.W. (1981, April 28). Reagan's Address on the Program for Economic Recovery. Speech broadcast live on radio and television, House Chamber of the United States Capitol, Washington, D.C. http://millercenter.org/president/speeches/detail/5446 
Reagan, R. W. (1983, September). Address to the Nation on the Soviet Attack on a Korean Civilian Airliner. Speech broadcasted live on nationwide television and radio, Oval Office, Washington, D.C. http://www.reagan.utexas.edu/archives/speeches/1983/90583a.htm

Reagan, R. W. (1984, June). Remarks at a Ceremony Commemorating the $40^{\text {th }}$ Anniversary of the Normandy Invasion, D-Day. Speech televised to the nation, Pointe du Hoc, Normandy. http://www.reagan.utexas.edu/archives/speeches/1984/60684a.htm

Reagan, R.W. (1987, March 4). Reagan's Address to the Nation on Iran-Contra. Speech broadcast live on nationwide radio and television, Oval Office, Washington, D.C. http://millercenter.org/president/speeches/detail/3414

Reagan, R.W. (1989, January 11). Farewell Address. Speech broadcast live on radio and television, Oval Office, Washington, D.C. http://millercenter.org/president/speeches/detail/3418

Renka, R. (2010, January 20). The Modern Presidency from Roosevelt through Barack Obama. Southeast Missouri State University. Retrieved April 1, 2013, from http://cstlcla.semo.edu/renka/ui320-75/renka_papers/mod_pres.asp

Ricoeur, P. (1994). “History and Rhetoric.” In Bédarida, F., The Social Responsibility of the Historian. 7-24. Oxford, New York: Berghahn.

Riehl, J. (2008). The Next Great Communicator? A Comparison of the Rhetorical Styles of Ronald Reagan and Barack Obama. Conference Papers - National Communication Association, 1.

Ritchie, D. A. (2007). Electing FDR: the New Deal campaign of 1932. United States of America: University Press of Kansas. 
Ronald Reagan: "Inaugural Address," January 20, 1981. Online by Gerhard Peters and John T. Woolley, The American Presidency Project. http://www.presidency.ucsb.edu/ws/?pid=43130.

Roof, W. (2009). American Presidential Rhetoric from Ronald Reagan to George W. Bush: Another Look at Civil Religion. Social Compass, 56(2), 286-301.

Roosevelt, F.D. (1933, March 4). 1933 Inaugural Address. Speech presented to the nation, Washington, D.C. http://millercenter.org/scripps/archive/speeches/detail/3280

Roosevelt, F. D. (1933, October 22). Fireside Chat 4 on Economic Progress. Speech broadcast via radio, Washington, D.C. http://millercenter.org/president/speeches/detail/3301

Roosevelt, F.D. (1941, December 9). Roosevelt Fireside Chat 19 on the War with Japan. Speech broadcast via radio, Washington, D.C. http://millercenter.org/president/speeches/detail/3325

Roosevelt, F. D. (1944, June). D-Day Prayer. Speech presented via radio, Washington, D.C. The American Presidency Project. http://www.presidency.ucsb.edu/ws/?pid=16515

Rosenthal, U., Charles, M. T., \& t' Hart, P. (Eds.). (1989). Coping with Crises: The Management of Disasters, Riots and Terrorism. Springfield, IL: Charles C. Thomas.

Rosenthal, U., Boin, R. A., \& Comfort, L. K. (2001). The Changing World of Crises and Crisis Management. In U. Rosenthal, R. Boin \& L. Comfort (Eds.), Managing Crises: Threats, Dilemmas, Opportunities, pp. 5-27. Springfield, IL: Charles C. Thomas.

Rottinghaus, B. (2006). Rethinking Presidential Responsiveness: The Public Presidency and Rhetorical Congruence, 1953-200 I. The Journal of Politics, 68, 720-732.

Ryan, H. R. (1979). Roosevelt's First Inaugural: A Study of Technique. Quarterly Journal Of Speech, 65(2), 137. 
Ryan, H. R. (1988). Franklin D. Roosevelt's Rhetorical Presidency. New York: Greenwood Press.

Ryfe, D. (1999). Franklin Roosevelt and the Fireside Chats. Journal Of Communication, 49(4), 80.

Schlesinger, R. (2008). White House Ghosts: Presidents and Their Speechwriters. New York: Simon \& Schuster. Print.

"Section II: Franklin D. Roosevelt and The New Deal." Scribd. Social Sciences Resource Guide, n.d. Web. http://www.scribd.com/doc/38987460/History-Part-II-Franklin-D-Rooseveltand-the-New-Deal >.

Seeger, M. W., Sellnow, T. L., \& Ulmer, R. R. (2003). Communication and Organizational Crisis. Westport, CT: Praeger.

Shamir, B. (1995). Social distance and charisma: Theoretical notes and a exploratory study. The Leadership Quarterly, 6, 19-47.

Shamir, B., Arthur, M. B., \& House, R. J. (1994). The rhetoric of charismatic leadership: A theoretical extension, a case study, and implications for research. The Leadership Quarterly, 5, 25-42.

Shamir, B., House, R. J., \& Arthur, M. B. (1993). The motivational effects of charismatic leadership: A self-concept based theory. Organization Science, 4, 577-594.

Shaw, D.R. (1999). A Study of Presidential Campaign Event Effects from 1952 to 1992. The Journal of Politics, 61, 387-422.

Sigelman, L. \& Whissell, C. (1992). "Projecting Presidential Personas on the Radio: An Addendum on the Bushes." Presidential Studies Quarterly, 32(3). 572-576. 
Stuckey, M. E. (2012). FDR, the Rhetoric of Vision, and the Creation of a National Synoptic State. Quarterly Journal Of Speech, 98(3), 297-319.

Stuckey, M. E. (2010). Rethinking the Rhetorical Presidency and Presidential Rhetoric. Review Of Communication, 10(1), 38-52. doi:10.1080/15358590903248744

The Text(ure) of the World in Presidential Rhetoric. (2012). Vital Speeches of the Day, 78(6), 171.

Tucker, R. C. (1968). The Theory of Charismatic Leadership. Daedalus, 97(3), 731-756.

Tully, G. (1949). FDR, My Boss. (p. 86) New York: C. Scribner's Sons.

Waldman, D. A., Ramirez, G. G., House, R. J., \& Puranam, P. (2001). Does leadership matter? CEO leadership attributes and profitability under conditions of perceived environmental uncertainty. Academy of Management Journal, 44, 134-143.

Walton, J. (2011). The Ethos Factor: Memorable and Forgettable Presidential Epideictic Oration. Young Scholars In Writing: Undergraduate Research In Writing And Rhetoric, 861-73.

Weaver, L., Sweeney, R. \& Thomas, B. (1984). “Communication during assassination attempts: Diffusion of information in attacks on President Reagan and the Pope." The Southern Speech Communication Journal, 49(3), 258.

Weber, M., Gerth, W. (1958). From Max Weber: Essays in Sociology.

Wichelns, H.A. “The Literary Criticism of Oratory.” In Drummond, A.M., Studies in Rhetoric and Public Speaking, In Honor of James Albert Winans. New York: Russell \& Russell.

Windt, T. (1983). The Presidency and Speeches on International Crises: Repeating the Rhetorical Past. Essays in Presidential Rhetoric, 126.

Winfield, B. (1990). FDR and the news media. (pp. 1-43). Urbana, Illinios: University of Illinois Press. 
Zarefsky, D. (1983). Civil Rights and Civil Conflict: Presidential Communication in Crisis. Central States Speech Journal, 34(1), 59-66.

Zhou, S. \& Sloan, WM. D. (2011). Research Methods in Communication. Northport, AL: Vision Press. 